\title{
Effect of enhanced whole-milk feeding in calves on subsequent first-lactation performance
}

\author{
D. J. Kiezebrink, ${ }^{*}$ A. M. Edwards, † T. C. Wright, $\ddagger$ J. P. Cant, ${ }^{*}$ and V. R. Osborne ${ }^{* 1}$ \\ *Department of Animal and Poultry Science, and \\ †Data Resource Center, McLaughlin Library, University of Guelph, Guelph, Ontario, Canada N1G 2W1 \\ $\ddagger$ Ontario Ministry of Agriculture, Food and Rural Affairs, Guelph, Ontario, Canada N1G 4Y2
}

\section{ABSTRACT}

The objective of this study was to determine the effect of enhanced whole-milk (WM) feeding systems in calves from birth to $8 \mathrm{wk}$ of age on subsequent firstlactation performance. The experiment was conducted as a completely randomized design consisting of 2 treatment groups. At birth, 152 Holstein heifer calves were randomly assigned to 1 of 2 treatments: (i) $4 \mathrm{~L}$ of $\mathrm{WM} / \mathrm{d}$ or (ii) $8 \mathrm{~L}$ of $\mathrm{WM} / \mathrm{d}$. The calves were bucket fed 2 or $4 \mathrm{~L}$ of WM twice daily at 0700 and $1600 \mathrm{~h}$. Each calf was housed individually in temperature-controlled nurseries and had ad libitum access to water and textured calf starter daily. Calves consumed greater volumes of textured calf starter when fed 4 versus $8 \mathrm{~L}$ of $\mathrm{WM} / \mathrm{d}$. Water intakes mirrored starter intakes, leading to greater water consumption at weaning. Calves reared on $8 \mathrm{~L}$ of $\mathrm{WM} / \mathrm{d}$ were heavier at $\mathrm{d} 56$ than calves reared on $4 \mathrm{~L}$ of $\mathrm{WM} / \mathrm{d}$. The average daily gain of the calves offered $8 \mathrm{~L}$ of $\mathrm{WM} / \mathrm{d}$ from d 0 to 56 was greater than that of calves offered $4 \mathrm{~L}$ of WM/d. Structural measurements were significantly greater for calves that consumed $8 \mathrm{~L}$ of $\mathrm{WM} / \mathrm{d}$. The differences observed in withers height and live BW due to WM feeding level were not apparent by 3 and 12 mo of age, respectively. Rumen $\mathrm{pH}$ was higher in calves that consumed $8 \mathrm{~L}$ of $\mathrm{WM} / \mathrm{d}$ than in calves that consumed $4 \mathrm{~L}$ of $\mathrm{WM} / \mathrm{d}$. Whole-milk feeding level did not affect age at first calving or milk-production parameters. These results suggest that enhanced WM feeding improved growth performance until 3 mo of age. However, first-lactation results indicated no lactation-performance benefits of increased nutrition and growth performance during the milk-fed period in dairy calves.

Key words: calf, enhanced feeding, whole milk, first lactation, growth

Received January 17, 2014.

Accepted September 22, 2014.

${ }^{1}$ Corresponding author: vosborne@uoguelph.ca

\section{INTRODUCTION}

Historically, research efforts in calf weaning have focused on feeding strategies that facilitate both early weaning and easy transition from liquid to solid feeding (Baldwin et al., 2004; Khan et al., 2011). These goals resulted in the "calf starter method" for raising replacement heifers in the 19th century (Savage and McCay, 1942). Increasing starter intake is the primary driver of ruminal epithelial development in calves because of the production of the VFA butyrate (Flatt et al., 1958; Sander et al., 1959; Quigley et al., 1991). Attempts to stimulate starter intake and rumen development led to limits of the amount of milk supplied to calves on commercial dairy farms. However, calves fed limited amounts of milk exhibit lower growth rates and abnormal behavior due to reduced nutrient intakes (Khan et al., 2011).

Over the past decade research has shifted to investigate the effects of increasing the supply of milk to young calves (Appleby et al., 2001; Diaz et al., 2001; Jasper and Weary, 2002). Recent studies have reported higher weight gains along with more natural behavior being expressed without stereotypes (Khan et al., 2011). Some research on enhanced milk or milk-replacer (MR) feeding has found that increased ADG during the first 2 mo of life results in significantly greater BW at 24 mo of age (Robelin and Chilliard, 1989; Moallem et al., 2010). Additionally, higher growth rates in early life have been observed to reduce age at first calving (Raeth-Knight et al., 2009) and increase milk yield (Bar-Peled et al., 1997; Moallem et al., 2010). However, not all literature agrees. Davis Rincker et al. (2011) and Terre et al. (2009) conducted similar experiments investigating the effects of enhanced MR feeding on subsequent first-lactation performance and found no significant results. Most enhanced feeding systems have focused on MR feeding with added protein concentrations. However, limited to no research has focused exclusively on whole-milk (WM) feeding on calf growth and later milk production.

The objective of the present study was to determine the effects of additional WM supply on growth per- 
Table 1. Ingredient and nutrient composition of textured calf starter, and heifer and lactating TMR

\begin{tabular}{|c|c|c|c|}
\hline \multirow[b]{2}{*}{ Item } & \multirow{2}{*}{$\begin{array}{c}\text { Calf } \\
\text { starter }\end{array}$} & \multicolumn{2}{|c|}{ TMR } \\
\hline & & Heifer & Lactating \\
\hline \multicolumn{4}{|l|}{ Ingredient ( $\%$ of DM) } \\
\hline Straw & & 18.4 & 1.8 \\
\hline Alfalfa silage & & 52.4 & 31.2 \\
\hline Corn silage & & 21.8 & 31.2 \\
\hline High-moisture corn & & & 21.9 \\
\hline Soybean meal (47\%) & & 6.4 & \\
\hline $\mathrm{LDC}^{1}$ supplement & & & 13.8 \\
\hline Premix & & 1.0 & \\
\hline \multicolumn{4}{|c|}{ Nutrient composition (DM basis) } \\
\hline $\mathrm{CP}(\%)$ & 18.0 & 14.6 & 16.3 \\
\hline $\operatorname{ADF}(\%)$ & 7.5 & 33.0 & 20.86 \\
\hline $\operatorname{NDF}(\%)$ & 22.8 & 49.4 & 33.30 \\
\hline $\mathrm{Ca}(\%)$ & 1.13 & 0.79 & 0.90 \\
\hline $\mathrm{P}(\%)$ & 0.69 & 0.34 & 0.45 \\
\hline $\mathrm{K}(\%)$ & 1.13 & 1.58 & 1.36 \\
\hline $\operatorname{Mg}(\%)$ & 0.28 & 0.26 & 0.30 \\
\hline $\mathrm{NE}_{\mathrm{M}}($ Mcal $/ \mathrm{kg})$ & 2.45 & 1.17 & 1.50 \\
\hline $\mathrm{NE}_{\mathrm{G}}(\mathrm{Mcal} / \mathrm{kg})$ & 1.72 & 0.61 & 0.91 \\
\hline $\mathrm{NE}_{\mathrm{L}}(\mathrm{Mcal} / \mathrm{kg})$ & & & 1.54 \\
\hline
\end{tabular}

${ }^{1} \mathrm{LDC}=$ lactating dairy cow.

formance during the neonatal period (birth to $8 \mathrm{wk}$ of age) and first-lactation performance in Holstein dairy cows. Based on previous findings, we hypothesized that WM feeding systems will significantly affect subsequent lactation performance.

\section{MATERIALS AND METHODS}

\section{Animals and Experimental Design}

This study used 152 Holstein heifer calves (initial $\mathrm{BW}$ of $42.2 \pm 3.8 \mathrm{~kg}$, mean $\pm \mathrm{SD}$ ) that were housed in an insulated and mechanically ventilated nursery at the Elora Dairy Research Center, University of Guelph (Guelph, Ontario, Canada). Animals were cared for and handled in accordance with the Canadian Council of Animal Care regulations. The University of Guelph Animal Care Committee reviewed and approved the experiment and all procedures carried out in the study. Calves were separated from dams at birth and placed in individual $1.2 \times 1.5 \mathrm{~m}$ pens bedded with kiln-dried wood shavings. The calves were fed $2 \mathrm{~L}$ of pooled colostrum within $90 \mathrm{~min}$ of birth and a second $2 \mathrm{~L}$ of colostrum 8 to12 $\mathrm{h}$ after the first colostrum feeding, and calves were offered WM until $56 \mathrm{~d}$ of age.

The study was conducted as a completely randomized design with a $2 \times 2$ factorial arrangement of treatments that took place over a 2-yr period of calvings (2005-2007). The calves were assigned at birth to 1 of 4 treatments: 1) $10 \mathrm{~h}$ of light, $14 \mathrm{~h}$ of dark, and $4 \mathrm{~L} / \mathrm{d}$ of $\mathrm{WM}$; 2) $10 \mathrm{~h}$ of light, $14 \mathrm{~h}$ of dark, and $8 \mathrm{~L} / \mathrm{d}$ of WM; 3) $18 \mathrm{~h}$ of light, $6 \mathrm{~h}$ of dark, and $4 \mathrm{~L} / \mathrm{d}$ of WM; and 4)
$18 \mathrm{~h}$ of light, $6 \mathrm{~h}$ of dark, and $8 \mathrm{~L} / \mathrm{d}$ of WM. The effect of light had no significant effect on this experiment and was removed from the statistical model (data not shown). A total of $n=160$ calves were entered on the trial, with 3 and 5 calves being removed from the experiment because of Escherichia coli infections for the 4-L and 8-L treatments, respectively. Fecal scores were recorded daily (d 0-56) using a 4-point scale, where $1=$ normal; $2=$ soft, not holding form; $3=$ runny, spreads easily; and $4=$ devoid of solid matter. No difference in fecal score for treatments was observed, and data are not shown.

The present study is reported as a completely randomized design that consisted of 2 treatments: 1) $4 \mathrm{~L}$ of WM per day $(\mathrm{n}=77)$ and 2$) 8 \mathrm{~L}$ of $\mathrm{WM}$ per day (n $=75$ ). The calves were bucket-fed WM that was offered for $30 \mathrm{~min}$ in equal-sized meals twice daily at 0700 and $1600 \mathrm{~h}$ and had free access to water and a standard textured calf starter (Rumax 20\% calf starter, Floradale Feed Mill Limited, Floradale, Ontario, Canada) throughout the study. Milk, water, and starter intakes were recorded daily. The chemical analysis of the calf starter is presented in Table 1.

Calves were weighed and measured for withers height weekly to $8 \mathrm{wk}$ of age. Calves were weighed on a platform scale (Salter Scales, Fairfiend, NJ), and withers heights were measured using a sliding-scale height stick with a bubble level. After weaning at d 56, live weight and withers height were recorded at wk 12, 16, 20, and 24 and BW at 12, 18, and 24 mo of age. After abrupt weaning, calves from both treatments were commingled and managed the same according to the standard operating procedures of the research facility. From weaning until 6 mo of age calves were housed in group pens and received the same treatment starter ration at $2.5 \mathrm{~kg} /$ head per day and allowed ad libitum access to alfalfa hay and water. At 6 mo of age through to lactation heifers received a TMR. Composition of the heifer and lactating TMR is provided in Table 1.

Ruminal fluid was aspirated $4 \mathrm{~h}$ after feeding on $\mathrm{d} 28$, 35,42 , and 56 using a Geishauser oral probe (Geishauser, 1993). A 200-mL sample of the rumen fluid was extracted and filtered through cheese cloth, and filtrate $\mathrm{pH}$ was measured immediately using a Fisher Accumeter (model 610, Fisher Scientific, Hampton, NH) calibrated using pH 4.0 and 7.0 buffer solutions (Fisher Scientific).

\section{Chemical Analysis}

Samples of calf starter were taken from each $20-\mathrm{kg}$ bag when it was opened, and they were composited monthly. Analytical DM content of the starter was determined by oven drying at $135^{\circ} \mathrm{C}$ for $2 \mathrm{~h}$ (method 
3.002; AOAC, 1990), and OM was determined by ashing at $500^{\circ} \mathrm{C}$ for $16 \mathrm{~h}$ (method 942.05, AOAC, 1990). The CP contents were determined using a Leco FP 428 nitrogen analyzer (Leco Corporation, St. Louis, MO). The calf-starter samples were also analyzed for ADF (method 973.18c; AOAC, 1990) and NDF (Van Soest et al., 1991) using $\alpha$-amylase (no. A3306, Sigma Chemical Co., St. Louis, MO) and sodium sulfite corrected for ash concentration adapted from an Ankom 200 fiber analyzer (Ankom Technology, Fairport, NY). Calcium, phosphorus, potassium, magnesium, and sodium were analyzed by inductively coupled plasma spectroscopy (method 945.46; AOAC, 1990).

Samples of fresh, whole, unpasteurized milk diverted from the parlor and that was offered during the experimental period were collected once per week and analyzed for fat, protein, and lactose by infrared spectrometry (method 972.16; AOAC, 1990). The average DM content of the WM was $13.3 \%$, which contained $31.6 \%$ fat, $26.8 \%$ protein, $34.1 \%$ lactose, and $7.5 \%$ ash. Calves offered $4 \mathrm{~L} / \mathrm{d}$ of WM or $8 \mathrm{~L} / \mathrm{d}$ of WM received a total of $532 \mathrm{~g} / \mathrm{d}$ or $1,064 \mathrm{~g} / \mathrm{d}$ of DM from WM, respectively. The ME of WM was calculated to be $5.2 \mathrm{Mcal} / \mathrm{L}$ (NRC, 2001).

\section{Lactation Variables}

Complete 305-d first-lactation milk yield and composition data produced by the multiple-trait procedure (ICAR, 2012) were obtained from the Canadian Dairy Network (Guelph, Ontario). Animals from the present study that were used in other research trials as lactating cows were omitted from our analysis. Calves that completed a first lactation and were not on another trial or not culled resulted in $n=53$ and $n=58$ for the 4-L and 8-L treatments, respectively.

\section{Statistical Analysis}

A repeated measures ANOVA for weight gain, ADG, water intake, calf-starter DMI, $\mathrm{pH}$, as well as structural body measurements was conducted using the MIXED procedure of SAS (v. 9.1, SAS Institute Inc., Cary, NC), according to the model $Y_{i j k}=\mu+\alpha_{i}+\beta_{j}+\alpha \beta_{i j}$ $+\gamma \cdot \mathrm{btw}_{i j k}+\delta \cdot \mathrm{btm}_{i j k}+\varepsilon_{k(i j)}$, where $Y_{i j k}$ is the dependent variable, $\mu$ is the overall mean, $\alpha_{i}$ is the effect of $\operatorname{diet}(i$ $=1,2), \beta_{j}$ is the repeated effect of week $(j=1$ to 8$)$, $\alpha \beta_{i j}$ is the effect of a diet $\times$ week interaction, btw ${ }_{i j k}$ is the birth weight of each calf ( $k=1$ to 77 ), $\gamma$ is the slope for the btw covariate, btm $_{i j k}$ is the birth month of each calf, $\delta$ is the slope of the btm covariate, and $\varepsilon_{k(i j)}$ is the random residual error. Mean comparisons done at each week were done using a difference among treatment means tested for significance using Tukey's multiple range test (v. 91, SAS Institute Inc.). The effect of diet was considered fixed.

Lactation variables including milk yield, fat yield, protein yield, fat percentage, and protein percentage were analyzed using the model $Y_{i j}=\mu+\alpha_{i}+\beta \cdot \operatorname{agc}_{i j}+$ $\varepsilon_{j(i)}$, where $Y_{i j}$ is the dependent variable, $\mu$ is the overall mean, $\alpha_{i}$ is the effect of diet $(i=1,2), \operatorname{agc}_{i j}$ is the effect of age at calving for each animal $(j=1$ to 58$), \beta$ is the slope of the age covariate, and $\varepsilon_{j(i)}$ is the random residual error. The effect of diet was considered fixed. A power calculation was used to determine the minimum sample size. Based on the calculation described by Berndtson (1991), a 0.89 power result was calculated, which gives a high probability of detecting a significant result between treatments.

Effects were considered significant at $P<0.05$. Mean comparisons among treatments were tested for significance using the least squares means test (v. 9.1, SAS Institute Inc.). Data are expressed as mean \pm SEM, which represents the pooled SE for the model.

\section{RESULTS AND DISCUSSION}

\section{Intakes}

Milk Intake. Calves offered the $8 \mathrm{~L}$ of WM consumed about $71 \%$ of milk in wk 1 , and from wk 2 to 8 consumption of milk offered averaged $92 \%$. The weekly least squares mean total intakes (L/wk) of WM for $4 \mathrm{~L}$ was $25.1,26.9,27.7,27.8,27.9,27.9,28.0,27.7$ and for $8 \mathrm{~L}$ was $39.8,49.8,51.8,51.6,51.4,52.0,51.8,50.9$ for wk $1,2,3,4,5,6,7$, and 8 , respectively.

Water Intake. Water intake from birth to weaning at d 56 is presented in Figure 1. Calves offered 4 $\mathrm{L} / \mathrm{d}$ of WM consumed an average of $11 \%$ more water than calves who received $8 \mathrm{~L} / \mathrm{d}$ of $\mathrm{WM}(P<0.009)$. At weaning, calves offered 4 and $8 \mathrm{~L} / \mathrm{d}$ of WM consumed 2.66 and $2.27 \mathrm{~L} / \mathrm{d}$ of water, respectively. These results agree with de Passillé et al. (2011) and Hepola et al. (2008), who reported higher water intakes in calves fed limited quantities of milk. In contrast, higher starter intakes tend to increase the quantity of water consumed (Kertz et al., 1984).

Starter Intake. Calf-starter intake from birth to weaning (d 56) is presented in Figure 1. It has been well established that increasing the amount of milk (WM or MR) offered to calves reduces their consumption of starter (Hepola et al., 2008; Bach, 2012). In the current study, starter DM dropped on an as-fed basis from $0.64 \mathrm{~kg} / \mathrm{d}$ by calves offered $4 \mathrm{~L} / \mathrm{d}$ of WM to $0.26 \pm 0.03 \mathrm{~kg} / \mathrm{d}$ by calves offered $8 \mathrm{~L} / \mathrm{d}$ of $\mathrm{WM}(P<$ $0.001)$, indicating that WM is preferred over starter as 

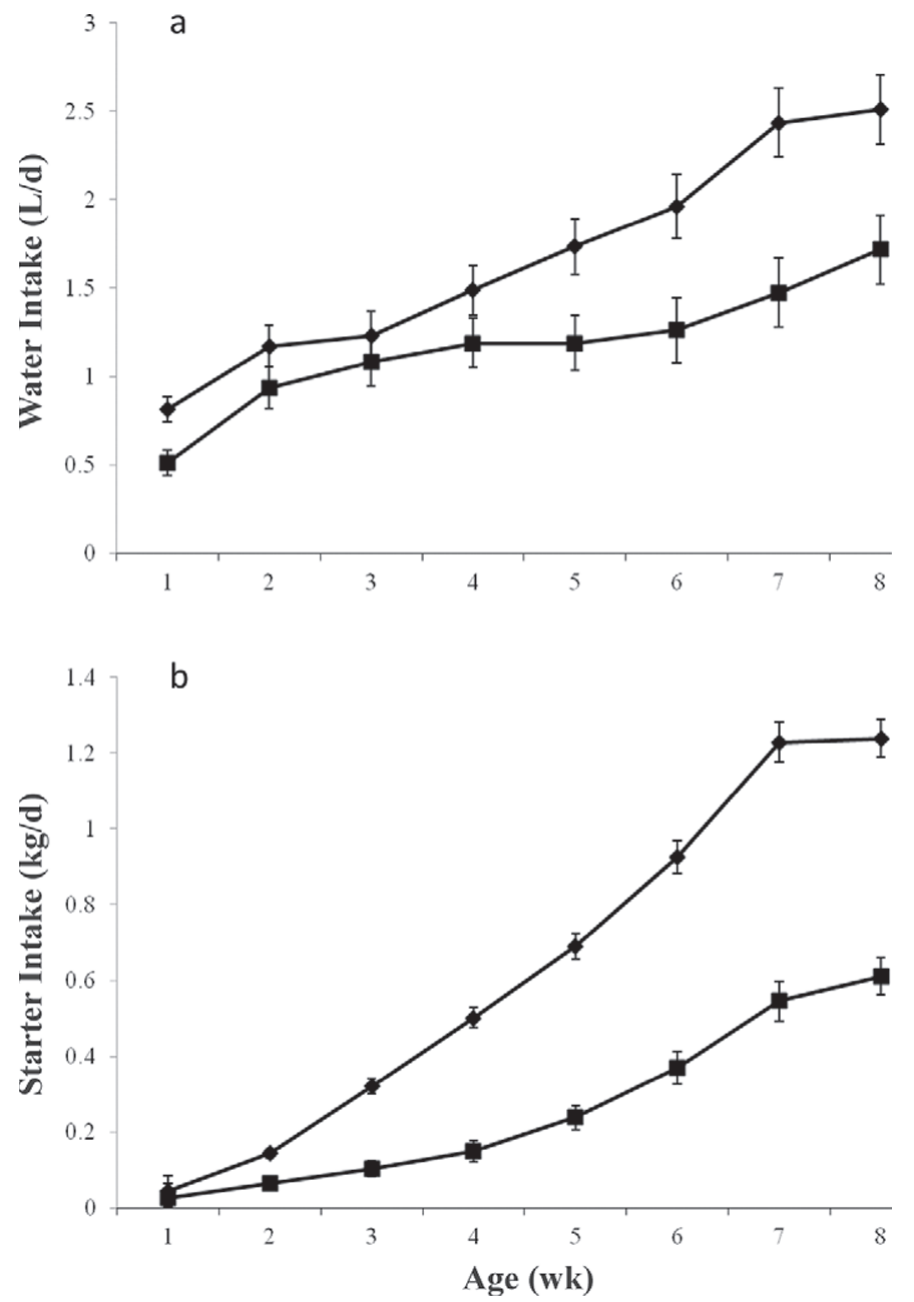

Figure 1. Effects of enhanced whole-milk feeding on (a) water intake and (b) starter intake of dairy calves from wk 1 to 8 . Calves fed $4 \mathrm{~L} / \mathrm{d}$ of whole milk $(\mathrm{n}=77$; $)$; calves fed $8 \mathrm{~L} / \mathrm{d}$ of whole milk $(\mathrm{n}=$ 75 ; $)$. All time periods are significant $(P<0.01)$ except wk 2,3 , and 4 for water intake, and all time periods are significant $(P<0.001)$ for starter intake.

a source of nutrients. Similar results were observed by Quigley et al. (2006) and Morrison et al. (2009), who reported average concentrate intakes of $0.43 \mathrm{~kg} / \mathrm{d}$ in calves fed $5 \mathrm{~L} / \mathrm{d}$ of $\mathrm{MR}$ and $0.28 \mathrm{~kg} / \mathrm{d}$ in calves fed 10
$\mathrm{L} / \mathrm{d}$ of MR, respectively. Calves offered lower amounts of WM consume significant quantities of starter earlier than calves offered greater quantities of milk. This may imply a balance between the amounts of WM fed and starter consumed to maximize growth potential during the neonatal period and to facilitate a smooth diet transition at weaning (Morrison et al., 2009).

\section{Ruminal pH}

Ruminal pH from d 29 to 56 is presented in Table 2. Diet had a significant effect on rumen $\mathrm{pH}$, where calves fed $8 \mathrm{~L} / \mathrm{d}$ of WM consistently had higher $\mathrm{pH}$ preweaning. Butyrate and propionate are used as energy sources by the rumen epithelium and have the greatest influence on epithelial development (Sander et al., 1959; Tamate et al., 1962). However, there is little awareness regarding the potential for subacute ruminal acidosis on health and production in growing dairy calves (Stone, 2004) caused by higher intakes of calf concentrates (Kristensen et al., 2007). As well, milk-fed calves may experience a condition known as ruminal drinking (van Weeren-Keverling, 1989), caused by a dysfunctional esophageal groove reflex that allows milk to enter into the reticulorumen (Bruinessen-Kapsenberg et al., 1982; Dirr and Dirksen, 1989). Lactose and carbohydrates from starter may be fermented by rumen microflora, creating elevated levels of organic acids that, if severe, produce acidosis (Gentile, 1995). In the current experiment, ruminal $\mathrm{pH}$ did not reach the level of acute acidosis, but values below 5.8 were recorded, which are indicative of a subacute situation (Kitkas et al., 2011).

\section{Growth Performance}

$\boldsymbol{A D G}$ and $\boldsymbol{B} \boldsymbol{W}$. Average daily gain and live BW are presented in Tables 3 and 4 , respectively. Calves offered $4 \mathrm{~L} / \mathrm{d}$ of WM grew an average of $0.62 \mathrm{~kg} / \mathrm{d}$, whereas calves offered $8 \mathrm{~L} / \mathrm{d}$ of WM grew $0.16 \mathrm{~kg} / \mathrm{d}$ faster $(P<0.001)$ at $0.78 \mathrm{~kg} / \mathrm{d}$ during the period from birth to weaning (Table 3). Calves offered $8 \mathrm{~L} / \mathrm{d}$ of

Table 2. Rumen $\mathrm{pH}$ for calves offered 4 versus $8 \mathrm{~L} / \mathrm{d}$ of whole milk

\begin{tabular}{|c|c|c|c|c|c|}
\hline \multirow[b]{3}{*}{ Rumen $\mathrm{pH}$} & \multicolumn{4}{|c|}{ Whole-milk feeding level (L/d) } & \multirow[b]{3}{*}{$P$-value } \\
\hline & \multicolumn{2}{|c|}{ Treatment $1(\mathrm{n}=77)$} & \multicolumn{2}{|c|}{ Treatment $2(\mathrm{n}=75)$} & \\
\hline & $4 \mathrm{~L}$ & $\mathrm{SE}$ & $8 \mathrm{~L}$ & SE & \\
\hline Wk 4 & 5.81 & 0.07 & 6.02 & 0.07 & 0.03 \\
\hline Wk 5 & 5.83 & 0.06 & 6.0 & 0.06 & 0.04 \\
\hline Wk 6 & 5.93 & 0.06 & 6.09 & 0.06 & 0.07 \\
\hline Wk 7 & 5.87 & 0.06 & 6.11 & 0.06 & 0.07 \\
\hline Wk 8 & 5.77 & 0.06 & 5.97 & 0.06 & 0.02 \\
\hline
\end{tabular}


Table 3. Average daily gain $(\mathrm{g} / \mathrm{d})$ for calves offered 4 versus $8 \mathrm{~L} / \mathrm{d}$ of whole milk for $56 \mathrm{~d}$

\begin{tabular}{|c|c|c|c|c|c|}
\hline \multirow{3}{*}{$\begin{array}{l}\mathrm{ADG} \\
(\mathrm{g} / \mathrm{d})\end{array}$} & \multicolumn{4}{|c|}{ Whole-milk feeding level (L/d) } & \multirow[b]{3}{*}{$P$-value } \\
\hline & \multicolumn{2}{|c|}{ Treatment $1(\mathrm{n}=77)$} & \multicolumn{2}{|c|}{ Treatment $2(\mathrm{n}=75)$} & \\
\hline & $4 \mathrm{~L}$ & SE & $8 \mathrm{~L}$ & $\mathrm{SE}$ & \\
\hline d 0 to 14 & 152.3 & 0.03 & 428.9 & 0.03 & $<0.0001$ \\
\hline d 15 to 28 & 586.8 & 0.04 & 896.2 & 0.04 & 0.0012 \\
\hline d 0 to 28 & 369.5 & 0.02 & 662.6 & 0.02 & $<0.0001$ \\
\hline d 29 to 42 & 776.5 & 0.03 & 813.7 & 0.03 & 0.37 \\
\hline d 43 to 56 & 975.2 & 0.04 & 962.0 & 0.04 & 0.84 \\
\hline d 29 to 56 & 875.8 & 0.03 & 887.8 & 0.03 & 0.77 \\
\hline d 0 to 56 & 622.7 & 0.02 & 775.2 & 0.02 & $<0.0001$ \\
\hline
\end{tabular}

WM had higher growth rates from birth to $28 \mathrm{~d}$ of life, and by $\mathrm{d} 28$ they were an average of $7 \mathrm{~kg}$ heavier $(P<$ $0.001)$ than calves offered $4 \mathrm{~L} / \mathrm{d}$ of WM after correcting for birth weight (Table 4). From d 28 to weaning, ADG was not different between treatments $(P>0.45)$, so calves offered $8 \mathrm{~L}$ of $\mathrm{WM} / \mathrm{d}$ remained $7 \mathrm{~kg}$ heavier at weaning $(P<0.001)$ after birth-weight correction. This difference in BW did not change but remained significant up to and including 52 wk of age. However, beyond $52 \mathrm{wk}, \mathrm{SE}$ increased to the point that a $7-\mathrm{kg}$ difference in BW could no longer be detected. Similar results were observed by Morrison et al. (2012), where BW differences had disappeared by 84 to 126 wk of age. However, in contrast to our experiment, others (Morrison et al., 2009; Davis Rincker et al., 2011) found no difference in body live weight by 12 wk of age.

Figure 2 shows the average daily intake of $\mathrm{ME}$ (Mcal/d) by week from WM and starter for the neonatal period. The average daily intake of ME (Mcal) throughout the $56 \mathrm{~d}$ was 4.36 and $5.61 \pm 0.08(P<$ 0.0001 ) for the calves fed 4 and $8 \mathrm{~L}$ of $\mathrm{WM}$, respec- tively. The total CP intake from WM and starter $(\mathrm{g} / \mathrm{d})$ for the first $56 \mathrm{~d}$ of life was 238 and $294 \mathrm{~g} / \mathrm{d}$ for the 4 -L and 8-L treatments, respectively. The total ME and CP values are similar to those found by others feeding WM (Moallem et al., 2010).

Structural Development. Withers height measurements are presented in Table 5. From wk 4 until wk 12 , calves fed $8 \mathrm{~L} / \mathrm{d}$ of $\mathrm{WM}$ were taller $(P<0.05)$ than calves receiving $4 \mathrm{~L} / \mathrm{d}$ of $\mathrm{WM}$. At weaning the difference in withers height was $1.2 \mathrm{~cm}$. Previous experiments have shown increased skeletal growth and body condition in calves fed higher amounts of WM or MR during the preweaning period (Shamay et al., 2005; Morrison et al., 2009). Contrary to these findings, Morrison et al. (2012) observed no effect of increasing MR intake from 500 to $1,250 \mathrm{~g} / \mathrm{d}$ on withers height at any stage of development, despite faster BW gains pre- and postweaning. Shamay et al. (2005) noted that differences in withers height disappeared shortly after weaning. In the current experiment, no significant differences in withers height after 3 mo of age existed.

Table 4. Live weight $(\mathrm{kg})$ for calves offered 4 versus $8 \mathrm{~L} / \mathrm{d}$ of whole milk

\begin{tabular}{|c|c|c|c|c|c|}
\hline \multirow{3}{*}{$\begin{array}{l}\text { Live weight } \\
(\mathrm{kg})\end{array}$} & \multicolumn{4}{|c|}{ Whole-milk feeding level (L/d) } & \multirow[b]{3}{*}{$P$-value } \\
\hline & \multicolumn{2}{|c|}{ Treatment $1(\mathrm{n}=77)$} & \multicolumn{2}{|c|}{ Treatment $2(\mathrm{n}=75)$} & \\
\hline & $4 \mathrm{~L}$ & $\mathrm{SE}$ & $8 \mathrm{~L}$ & $\mathrm{SE}$ & \\
\hline Wk 1 & 43.37 & 0.26 & 44.58 & 0.24 & $<0.0001$ \\
\hline Wk 2 & 45.64 & 0.39 & 49.84 & 0.37 & $<0.0001$ \\
\hline Wk 3 & 49.18 & 0.55 & 55.86 & 0.51 & $<0.0001$ \\
\hline Wk 4 & 53.88 & 0.66 & 61.83 & 0.61 & $<0.0001$ \\
\hline Wk 5 & 58.86 & 0.74 & 67.04 & 0.69 & $<0.0001$ \\
\hline Wk 6 & 64.56 & 0.86 & 72.72 & 0.80 & $<0.0001$ \\
\hline Wk 7 & 70.97 & 1.05 & 78.66 & 0.97 & $<0.0001$ \\
\hline Wk 8 & 78.11 & 1.19 & 85.77 & 1.10 & $<0.0001$ \\
\hline Wk 12 & 107.12 & 1.58 & 112.36 & 1.45 & 0.02 \\
\hline Wk 16 & 130.87 & 1.89 & 134.20 & 1.75 & 0.21 \\
\hline Wk 20 & 154.25 & 2.15 & 161.23 & 1.95 & 0.02 \\
\hline Wk 24 & 179.48 & 2.06 & 186.36 & 2.03 & 0.02 \\
\hline Wk 52 & 353.44 & 4.04 & 365.57 & 3.98 & 0.03 \\
\hline Wk 78 & 489.81 & 5.63 & 501.65 & 5.55 & 0.14 \\
\hline Wk 104 & 594.99 & 9.64 & 589.84 & 9.47 & 0.70 \\
\hline
\end{tabular}




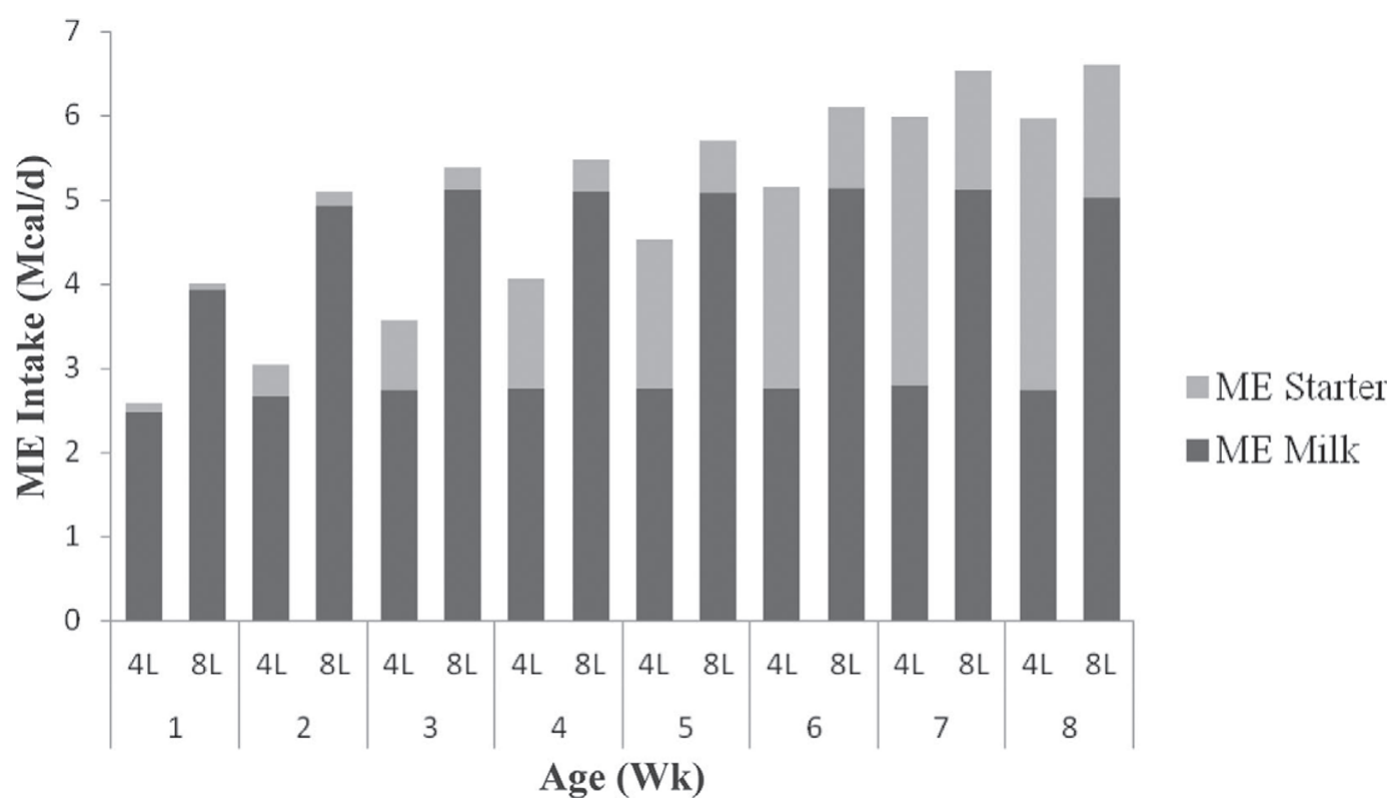

Figure 2. The effect on total ME (Mcal/d) intake from whole milk and calf starter for calves fed $4 \mathrm{~L} / \mathrm{d}(\mathrm{n}=77)$ or $8 \mathrm{~L} / \mathrm{d}$ of whole milk (n $=75)$. All time periods are significant $(P<0.0001)$ except wk $7(P<0.01)$ and wk $8(P<0.001)$.

\section{Lactation Performance}

First-lactation variables are presented in Table 6 . Treatment did not affect age at first calving, postcalving BW, or milk yield and composition in the first lactation. Many studies have found no effect of increasing MR intake during the neonatal period on first-lactation performance (Morrison et al., 2009; Raeth-Knight et al., 2009; Terre et al., 2009). However, these studies differed slightly from the current study in the experimental protocol, looking at the effects of MR on lactation performance.
In contrast, several studies report positive associations between the level of liquid nutrition during the milk-feeding phase and subsequent first-lactation milk production (Bar-Peled et al., 1997; Shamay et al., 2005; Moallem et al., 2010). However, some differences exist between these studies and the present study. These differences may account for the increase in milk production seen in their results, whereas the current study observed none. Moallem et al. (2010) reported that heifers fed WM averaged $10 \%$ more milk produced than heifers fed MR. This increase in milk production was positively associated with increased protein concentrations fed

Table 5. Withers height $(\mathrm{cm})$ in calves offered 4 versus $8 \mathrm{~L} / \mathrm{d}$ of whole milk

\begin{tabular}{|c|c|c|c|c|c|}
\hline \multirow{3}{*}{$\begin{array}{l}\text { Withers } \\
\text { height }(\mathrm{cm})\end{array}$} & \multicolumn{4}{|c|}{ Whole-milk feeding level (L/d) } & \multirow[b]{3}{*}{$P$-value } \\
\hline & \multicolumn{2}{|c|}{ Treatment $1(\mathrm{n}=77)$} & \multicolumn{2}{|c|}{ Treatment $2(\mathrm{n}=75)$} & \\
\hline & $4 \mathrm{~L}$ & $\mathrm{SE}$ & $8 \mathrm{~L}$ & $\mathrm{SE}$ & \\
\hline Wk 1 & 78.12 & 0.26 & 78.25 & 0.27 & 0.72 \\
\hline Wk 2 & 78.92 & 0.26 & 79.11 & 0.28 & 0.62 \\
\hline Wk 3 & 80.07 & 0.32 & 80.52 & 0.33 & 0.33 \\
\hline Wk 4 & 81.27 & 0.29 & 82.40 & 0.31 & 0.01 \\
\hline Wk 5 & 83.01 & 0.33 & 84.35 & 0.35 & 0.01 \\
\hline Wk 6 & 84.56 & 0.31 & 85.76 & 0.33 & 0.01 \\
\hline Wk 7 & 86.62 & 0.35 & 87.59 & 0.36 & 0.06 \\
\hline Wk 8 & 88.56 & 0.37 & 89.76 & 0.39 & 0.03 \\
\hline Wk 12 & 94.26 & 0.41 & 95.80 & 0.43 & 0.01 \\
\hline Wk 16 & 99.32 & 1.58 & 98.06 & 1.66 & 0.59 \\
\hline Wk 20 & 103.54 & 0.50 & 104.58 & 0.50 & 0.16 \\
\hline Wk 24 & 107.58 & 0.43 & 108.50 & 0.44 & 0.15 \\
\hline
\end{tabular}


Table 6. First-lactation performance in calves offered different whole-milk treatments

\begin{tabular}{|c|c|c|c|c|c|}
\hline \multirow{3}{*}{$\begin{array}{l}\text { First-lactation } \\
\text { performance }\end{array}$} & \multicolumn{4}{|c|}{ Whole-milk feeding level (L/d) } & \multirow[b]{3}{*}{$P$-value } \\
\hline & \multicolumn{2}{|c|}{ Treatment $1(\mathrm{n}=53)$} & \multicolumn{2}{|c|}{ Treatment $2(\mathrm{n}=58)$} & \\
\hline & $4 \mathrm{~L}$ & $\mathrm{SE}$ & $8 \mathrm{~L}$ & $\mathrm{SE}$ & \\
\hline Age at first calving (mo) & 24.9 & 0.6 & 24.3 & 0.56 & 0.96 \\
\hline Postcalving weight (kg) & 595 & 9.64 & 590 & 9.50 & 0.70 \\
\hline 305-d milk production $(\mathrm{kg})$ & 8,725 & 163 & 8,700 & 154 & 0.91 \\
\hline Fat yield (kg) & 326 & 7.2 & 329 & 6.78 & 0.71 \\
\hline Protein yield $(\mathrm{kg})$ & 276 & 4.80 & 277 & 4.54 & 0.81 \\
\hline Fat $(\%)$ & 3.74 & 0.058 & 3.80 & 0.055 & 0.47 \\
\hline Protein (\%) & 3.16 & 0.020 & 3.19 & 0.019 & 0.30 \\
\hline
\end{tabular}

during the prepubertal age, as well as increased BW at calving (Moallem et al., 2010).

The current study, which is the first to investigate elevated WM feeding, found no milk-production benefits from increasing the amount of WM fed to individually housed calves in a temperature-controlled environment during the neonatal period. In addition, tradeoffs may exist between WM and starter as a source of nutrients during the neonatal period, later affecting lactation performance in subsequent lactations. Further research in this area is needed to better determine the cause and effect of enhanced WM feeding in calves on subsequent first-lactation performance.

\section{CONCLUSIONS}

Elevated daily WM feeding improved calf ADG preweaning and BW up to 52 wk of age. Higher WM feeding was associated with reduced starter intake preweaning, so there is a tradeoff to consider between WM and starter as sources of nutrients for the neonatal calf. Lower starter intake led to higher ruminal $\mathrm{pH}$, reducing the possibility of subacute ruminal acidosis. Postweaning, differences in live BW and skeletal growth were no longer apparent after 3 and 12 mo of age, respectively. Despite the improvements in growth during the preweaning period, no significant differences in age at first calving or milk yield existed. Though there are benefits of more natural behavior and improved health in calves offered higher quantities of WM, economic benefit may not be demonstrated in first-lactation performance. These data suggest that conventional WM feeding programs $(\sim 4 \mathrm{~L}$ of $\mathrm{WM} / \mathrm{d})$ are sufficient for neonatal nutrition for dairy heifers housed in an insulated, mechanically ventilated, controlled environment.

\section{ACKNOWLEDGMENTS}

The authors thank the staff at the Elora Dairy Research Center, University of Guelph, and Cana- dian Dairy Network for their technical assistance. The authors also thank the Dairy Farmers of Ontario and Ontario Ministry of Agriculture and Food for financial support.

\section{REFERENCES}

AOAC. 1990. Official Methods of Analysis. Vol. I. 15th ed. Assoc. Off. Anal. Chem., Arlington, VA.

Appleby, M. C., D. M. Weary, and B. Chua. 2001. Performance and feeding behavior of calves on ad libitum milk from artificial teats. Appl. Anim. Behav. Sci. 74:191-201.

Bach, A. 2012. Ruminant nutrition symposium: Optimizing performance of the offspring: Nourishing and managing the dam and post natal calf for optimal lactation, reproduction, and immunity. J. Anim. Sci. 90:1835-1845.

Baldwin, R. L. VI, K. R. McLeod, J. L. Klotz, and R. N. Heitmann. 2004. Rumen development, intestinal growth and hepatic metabolism in the pre- and postweaning ruminant. J. Dairy. Sci. 87(E. Suppl.):E55-E65.

Bar-Peled, U., B. Robinson, E. Maltz, H. Tagari, Y. Folman, I. Bruckental, H. Voet, H. Gacitua, and A. R. Lehrer. 1997. Increased weight gain and effects on production parameters of Holstein heifer calves that were allowed to suckle from birth to six weeks of age. J. Dairy Sci. 80:2523-2528.

Berndtson, W. E. 1991. A simple, rapid and reliable method for selecting or assessing the number of replicates for animal experiments. J. Anim. Sci. 69:67-76.

Bruinessen-Kapsenberg, E. G., T. van Wensing, and H. J. Breukink. 1982. Indigestionen der Mastka lber infolge fehlenden Schlundrinnenreflexes. Tierarztl. Umsch. 37:515-517.

Davis Rincker, L. E., M. J. Vandehaar, C. Wolf, J. S. Liesman, L. T. Chapin, and M. S. Weber Nielsen. 2011. Effect of intensified feeding of heifer claves on growth, pubertal age, calving age, milk yield, and economics. J. Dairy Sci. 94:3554-3567.

de Passillé, A. M., T. F. Borderas, and J. Rushen. 2011. Weaning age of calves fed a high milk allowance by automated feeders: Effects on feed, water, and energy intake, behavioral signs of hunger, and weight gains. J. Dairy Sci. 94:1401-1408.

Diaz, M. C., M. E. Van Amburgh, J. M. Smith, J. M. Kelsey, and E. L. Hutten. 2001. Composition of growth of Holstein calves fed milk replacer from birth to 105-kilogram body weight. J. Dairy Sci. 84:830-842.

Dirr, L., and G. Dirksen. 1989. Oesophageal groove dysfunction as a complication of neonatal diarrhea in the calf. Bovine Pract. 24:53-60.

Flatt, W. P., R. G. Warner, and J. K. Loosli. 1958. Influence of purified materials on the development of the ruminant stomach. J. Dairy Sci. 41:1593-1600.

Geishauser, T. 1993. An instrument for the collection and transfer of ruminal fluid and for the administration of water-soluble drugs in adult cattle. Bovine Pract. 27:38-42. 
Gentile, A. 1995. Untersuchungen über die Azidität der Pansenflüssigkeit von Kälbern nach intraruminaler Verabreichung von Rehydratationslösungen. Dtsch. Tierarztl. Wochenschr. 102:241-244.

Hepola, H. P., L. T. Hänninen, S. M. Raussi, P. A. Pursiainen, A. M. Aarnikoivu, and H. S. Saloniemi. 2008. Effects of providing water from a bucket or a nipple on the performance and behavior of calves fed ad libitum volumes of acidified milk replacer. J. Dairy Sci. 91:1486-1496.

ICAR (International Committee for Animal Recording). 2012. International Agreement of Recording Practices. Accessed Mar. 15, 2014. http://www.icar.org/Documents/Rules\%20and\%20regulations/ Guidelines/Guidelines_2012.pdf.

Jasper, J., and D. M. Weary. 2002. Effects of ad libitum milk intake on dairy calves. J. Dairy Sci. 85:3054-3058.

Kertz, A. F., L. F. Reutzel, and J. H. Mahoney. 1984. Ad libitum water intake by neonatal calves and its relationship to calf starter intake, weight gain, feces score, and season. J. Dairy Sci. 67:2964-2969.

Khan, M. A., D. M. Weary, and M. A. G. von Keyserlingk. 2011. Invited review: Effects of milk ration on solid feed intake, weaning, and performance in dairy heifers. J. Dairy Sci. 94:1071-1081.

Kitkas, G. C., N. Panousis, G. E. Valergakis, and C. Karatzias. 2011. Subacute ruminal acidosis in dairy cows. J. Hellenic Vet. Med. Soc. $62: 352-362$.

Kristensen, N. B., J. Sehested, S. K. Jensen, and M. Vestergaard. 2007. Effect of milk allowance on concentrate intake, ruminal environment, and ruminal development in milk-fed Holstein calves. J. Dairy Sci. 90:4346-4355.

Moallem, U., D. Werner, H. Lehrer, M. Zachut, L. Liveshitz, S. Yakoby, and A. Shamay. 2010. Long-term effects of ad libitum whole milk prior to weaning and prepubertal protein supplementation on skeletal growth rate and first-lactation milk production. J. Dairy Sci. 93:2639-2650.

Morrison, S. J., H. C. F. Wicks, A. F. Carson, R. J. Fallon, H. Twigge, D. J. Kilpatrick, and S. Watson. 2012. The effect of calf nutrition on the performance dairy herd replacements. Animal 6:909-919.

Morrison, S. J., H. C. Wicks, R. J. Fallon, J. Twigge, L. E. Dawson, A. R. Wylie, and A. F. Carson. 2009. Effects of feeding level and protein content of milk replacer on the performance of dairy herd replacements. Animal 3:1570-1579.

NRC. 2001. Nutrient Requirements of Dairy Cattle. 7th. rev. ed. Natl. Acad. Sci., Washington, DC.
Quigley, J. D., L. A. Caldwell, G. G. Sinks, and R. N. Heitman. 1991 Changes in blood glucose, non-esterified fatty acids, and ketones in response to weaning and feed intake in young calves. J. Dairy Sci. $74: 250-257$.

Quigley, J. D., T. A. Wolfe, and T. H. Elsasser. 2006. Effects of additional milk replacer feeding on calf health, growth, and selected blood metabolites in calves. J. Dairy Sci. 89:207-216.

Raeth-Knight, M., H. Chester-Jones, S. Hayes, J. Linn, R. Larson, and D. Ziegler. 2009. Impact of conventional or intensive milk replacer programs on Holstein heifer performance through six months of age and during first lactation. J. Dairy Sci. 92:799-809.

Robelin, J., and Y. Chilliard. 1989. Short-term and long-term effects of early nutritional deprivation on adipose tissue growth and metabolism in calves. J. Dairy Sci. 72:505-513.

Sander, E. G., R. G. Warner, H. N. Harrison, and J. K. Loosli. 1959. The stimulatory effect of sodium butyrate and sodium propionate on the development of rumen mucosa in the young calf. J. Dairy Sci. 42:1600-1605

Savage, E. S., and C. M. McCay. 1942. The nutrition of calves. A review. J. Dairy Sci. 25:595-650.

Shamay, A., D. Werner, U. Moallem, H. Barash, and I. Bruckental. 2005. Effect of nursing management and skeletal size at weaning on puberty, skeletal growth rate, and milk production during first lactation of dairy heifers. J. Dairy Sci. 88:1460-1469.

Stone, W. C. 2004. Nutritional approaches to minimize subacute ruminal acidosis and laminitis in dairy cattle. J. Dairy Sci. 87(E Suppl.):E13-E26.

Tamate, H., A. D. McGilliard, N. L. Jacobsen, and R. Getty. 1962. Effect of various dietaries on the anatomical development of the stomach in the calf. J. Dairy Sci. 45:408-420.

Terre, M., C. Tejero, and A. Bach. 2009. Long-term effects on heifer performance of an enhanced-growth feeding programme applied during the preweaning period. J. Dairy Res. 76:331-339.

Van Soest, P. J., J. B. Robertson, and B. A. Lewis. 1991. Methods for dietary fiber, neutral detergent fiber, and non-starch polysaccharides in relation to animal nutrition. J. Dairy Sci. 74:3583-3597.

van Weeren-Keverling, B. A. 1989. Ruminal Drinking in Veal Calves. Proefschrift, Utrecht, the Netherlands. 